\title{
B7-H4 expression and its role in interleukin-2/interferon treatment of clear cell renal cell carcinoma
}

\author{
YIPENG XU ${ }^{1}$, SHAOXING ZHU ${ }^{1}$, MEI SONG ${ }^{2}$, WEIHUI LIU ${ }^{3}$, CHENGYI LIU ${ }^{4}$, YONGSHENG LI ${ }^{5}$ and MIN WANG ${ }^{6}$ \\ Departments of ${ }^{1}$ Urology and ${ }^{2}$ Ultrasonography, Zhejiang Cancer Hospital, Hangzhou, Zhejiang 310022; \\ ${ }^{3}$ Department of Urology, Fujian Medical University Second Affiliated Hospital, Quanzhou, Fujian 362000; \\ ${ }^{4}$ Department of Urology, Lu'an Affiliated Hospital of Anhui Medical University, Lu'an, Anhui 237005; \\ ${ }^{5}$ Department of Urology, The Union Hospital of Fujian Medical University, Fuzhou, Fujian 350001; \\ ${ }^{6}$ Institute of Ophthalmology, Shandong Academy of Medical Sciences, Qingdao, Shandong 266071, P.R. China
}

Received July 9, 2013; Accepted December 16, 2013

DOI: 10.3892/ol.2014.1961

\begin{abstract}
The immunological mechanism mediated by $\mathrm{T}$ cells is the main therapeutic target in the treatment of renal cell carcinoma (RCC) with interleukin (IL)-2 and interferon (IFN) $-\alpha$. The aim of the present study was to evaluate the role of B7-H4 in the IL-2, IFN- $\alpha$ and IFN- $\gamma$ treatment of clear cell RCC (ccRCC). A total of 154 paraffin-embedded ccRCC tissues were studied using immunohistochemistry, which subsequently indicated that positive B7-H4 expression is associated with adverse clinical features in ccRCC. The effects of IL- 2 , IFN- $\alpha$ and IFN- $\gamma$ on B7-H4 expression in a ccRCC cell line were evaluated at the mRNA and protein levels. In addition, the effect of B7-H4 on the killing activity of T cells was detected. B7-H4 expression was identified to be upregulated by IL- 2 , IFN- $\alpha$ and IFN- $\gamma$, of which, IFN- $\gamma$ was the most capable. Additionally, blocking of B7-H4/B7-H4 ligand interactions may rescue the killing activity of $\mathrm{T}$ cells. Altogether, the observations of the current study showed that the immune escape pathway induced by B7-H4 may be one of the most important reasons for the low efficacy of IL-2 and IFN- $\alpha$ and the inability to observe the efficacy of IFN- $\gamma$ in mRCC. This indicates that B7-H4 may be used as a new molecular biology marker to select treatment options for patients with ccRCC.
\end{abstract}

\section{Introduction}

Renal cell carcinoma (RCC) is one of the most common types of malignant tumor of the human urinary system. To date, the benefit of conventional therapies for RCC, including

Correspondence to: Dr Shaoxing Zhu, Department of Urology, Zhejiang Cancer Hospital, 38 Guangji Road, Hangzhou, Zhejiang 310022, P.R. China

E-mail: zsxing2005@126.com

Key words: B7-H4, clear cell renal cell carcinoma, cytokines, tumor immunity surgical, radiological and chemotherapeutic approaches, is limited. Treatment with interferon (IFN) and interleukin (IL)-2 remains the main immunotherapy method for RCC, with the exception of surgery, but only $\sim 10 \%$ of advanced RCC patients respond to cytokine-based immunotherapy $(1,2)$. Therefore, more effective potential and combined therapies must be found. New targeted therapy for RCC may initiate a new avenue for cancer treatment, and targeted therapy depends on the evaluation of target gene status.

B7-H4, also called B7x/B7s/VTCN1, is the newest B7 superfamily member identified as an inhibitory modulator of the T-cell response. Combined with its receptor, B7-H4 may inhibit the proliferation and cytokine production of $\mathrm{CD}^{+}$and $\mathrm{CD}^{+} \mathrm{T}$ cells. The blocking of B7-H4/B7-H4 ligand interactions may restore antitumor T-cell responses to ovarian cancer cells (3). Previous studies have reported that the $\mathrm{B} 7-\mathrm{H}_{4}{ }^{+}$status is an independent predictor of poor prognosis in multivariate analysis (4-9). To date, few previous studies have analyzed the potential contributions of B7-H4 to tumoral immune escape and therapeutic targeting in RCC.

Herein, we present evidence for the potential contributions of B7-H4 to tumoral immune escape in ccRCC, which indicates that B7-H4 may be used as a new biological molecular marker for select treatment options in patients with ccRCC.

\section{Materials and methods}

Cell culture, antibodies and cytokines. The cell line, 786-0, was purchased from the Cell Bank at the Chinese Academy of Sciences (Beijing, China) and was cultured according to the manufacturer's instructions. The anti-B7-H4 antibody (Ab) was purchased from R\&D Systems (Minneapolis, MN, USA). Other Abs were purchased from Bioss (Beijing, China) and the cytokines (IL-2, IFN- $\alpha$ and IFN- $\gamma$ ) were purchased from Xiamen Amoytop Biotech Co., Ltd. (Xiamen, China).

RCC tissue. A total of 154 specimens of RCC tissue were collected from RCC patients undergoing radical nephrectomy in the Department of Urology, Zhejiang Cancer Hospital (Hangzhou, China). The final staging, grading and histological diagnosis were based on the pathology report. 
Ethics approval was obtained from the local Institution Review Board committee.

Immunohistochemistry (IHC) to tissue microarray (TMA) and 786-0 cells. IHC was performed using a polyclonal B7-H4 $\mathrm{Ab}$ at a dilution of 1:400. Antigen retrieval was performed by heating the slides for $7 \mathrm{~min}$ in $10 \mathrm{mM}$ citric acid buffer. The TMA consisted of cores from 154 patients with clear cell RCC (ccRCC). IHC was analyzed independently by two pathologists, and positive IHC was determined when $\geq 5 \%$ of the cells showed B7-H4 staining. The 786-0 cells were fixed by $4 \%$ paraformaldehyde and directly incubated with $\mathrm{B} 7-\mathrm{H} 4 \mathrm{Ab}$ at a dilution of 1:400. The remaining procedures were performed as described for the TMA.

Cell proliferation assay. Cell proliferation was quantitated by a Cell Counting Kit- 8 (CCK-8) assay to generate a growth inhibition ratio following stimulation with IL-2, IFN- $\alpha$ and IFN- $\gamma$ for $24 \mathrm{~h}$. 786-0 cells were seeded at 6,000 cells per well in a 96-well plate and incubated for $24 \mathrm{~h}$. The culture fluid, containing IL-2, IFN- $\alpha$ and IFN- $\gamma$ at the concentrations of 0 , $100,250,500,1,000,2,000,4,000$ and $8,000 \mathrm{U} / \mathrm{ml}$, was then added into each well and incubated for $24 \mathrm{~h}$. Next, $10 \mu \mathrm{l} \mathrm{CCK}-8$ was added into each well and incubated for $2 \mathrm{~h}$. Each well was read at $450 \mathrm{~nm}$ using a spectrophotometer (Eppendorf, Hamburg, Germany).

ELISA to cell culture supernatant. The protein of B7-H4 was diluted to $100,50,25,10,2,0.5$ and $0.1 \mathrm{ng} / \mathrm{ml}$ to be used as a standard. Samples were collected following centrifugation at 1,200 x g. In total, $40 \mu \mathrm{l}$ sample, $10 \mu \mathrm{l}$ anti-B7-H4 Ab and $50 \mu 1$ streptomycin-horseradish peroxidase were added into the ELISA kit and then incubated for $1 \mathrm{~h}$ at $37^{\circ} \mathrm{C}$. Following washing three times with phosphate-buffered saline (PBS), $100 \mu \mathrm{l}$ chromogenic agent was added to each well. In addition, $50 \mu \mathrm{l}$ stop buffer was added to each well following incubation for $15 \mathrm{~min}$ at $37^{\circ} \mathrm{C}$. The plates were then read at $450 \mathrm{~nm}$ using a spectrophotometer. The minimum detectable concentration was determined to be $>0.1 \mathrm{ng} / \mathrm{ml}$.

Reverse transcription ( $R T)$-polymerase chain reaction (PCR). Total RNA was extracted from the 786-0 cells using TRIzol reagent (Invitrogen Life Technologies, Carlsbad, CA, USA) following stimulation with IL-2, IFN- $\alpha$ and IFN- $\gamma(1,000 \mathrm{U} / \mathrm{ml})$ for $24 \mathrm{~h}$. A total of $2 \mu \mathrm{g}$ RNA was reverse-transcribed using avian myeloblastosis virus reverse transcription XL (Toyobo Co. Ltd, Shanghai, China) for $90 \mathrm{~min}$ at $42^{\circ} \mathrm{C}$ in the presence of oligo(dT) primer (Fermentas, Waltham, MA, USA). PCR was performed using Taq polymerase. The primer sequences (Ying Wei Chuang, Guangzhou, China) used were as follows: B7-H4 forward, 5'-CACTCATCATTGGCTTTGGTATTTCAG-3' and reverse, 5'-CGACAGCTCATCTTTGCCTTCTTTG-3'; and actin forward, 5'-AGCGGGAAATCGTGCGTGAC-3' and reverse, 5'-ACTCCTGCTTGCTGATCCATATC-3'. PCR was performed for 35 cycles, which consisted of a pre-soak for $5 \mathrm{~min}$ at $94^{\circ} \mathrm{C}$, denaturing for $30 \mathrm{sec}$ at $94^{\circ} \mathrm{C}$, annealing for $30 \mathrm{sec}$ at $56^{\circ} \mathrm{C}$ and extension for $30 \mathrm{sec}$ at $72^{\circ} \mathrm{C}$. Following completion of the cycle, the amplified products were electrophoresed through a $1 \%$ agarose gel and stained with ethidium bromide. Images were captured under an ultraviolet light transilluminator (Syngene Co., Cambrisge, UK).

Flow cytometry. The surface expression of B7-H4 on the 786-0 cell line following stimulation with IL-2, IFN- $\alpha$ and IFN- $\gamma$ was quantified by flow cytometry on a fluorescence-activated cell sorter (FACs). For each analysis, 10,000 cells were evaluated. For detecting intracellular B7-H4 expression, the 786-0 cells were pre-permeabilized with permeabilization buffer for $10 \mathrm{~min}$. Following washing twice with PBS, the cells were further fixed by fixation buffer (4\% paraformaldehyde) and then B7-H4 monoclonal Abs (mAbs) were added. Following extreme washing with PBS, B7-H4 expression was further detected by FACs. The FACs results were analyzed using CELLQuest ${ }^{\mathrm{TM}}$ software (BD Biosciences, Franklin Lakes, NJ, USA).

Functional cytotoxic assays with blocking B7-H4 mAb. Lymphoblastoid cell lines were established from mononuclear cells collected from the peripheral blood of healthy donors by Ficoll-Hypaque centrifugation. All individuals provided written informed consent. The cells were incubated with concanavalin A $(1,2,4$ and $8 \mu \mathrm{g} / \mathrm{ml})$ for $48 \mathrm{~h}$, and CCK-8 was performed to detect the lymphocyte proliferation rate of the $\mathrm{T}$ cells. Functional assays were performed by incubation of the T cells for $48 \mathrm{~h}$, in the absence or presence of isotypic control (purified mouse IgG1 $\kappa$ ) or B7-H4 blocking mAb. The cytotoxic effect on the T cells was evaluated by CCK-8, which identifies apoptotic cells.

Statistical analyses. SPSS version 13.0 (SPSS, Inc., Chicago, IL, USA) and Microsoft Excel 2003 (Microsoft Corporation, Redmond, WA, USA) were used for the statistical analyses. $\mathrm{P}<0.05$ was considered to indicate a statistically significant difference.

\section{Results}

Increased B7-H4 expression is associated with adverse clinical features. In total, 91 (59.09\%) patient specimens exhibited positive tumor B7-H4 staining (Fig. 1A). A comparison of clinical features by tumor B7-H4 expression is shown in Table I. Positive tumor B7-H4 expression was associated with adverse clinical features, including tumor-node-metastasis and clinical stages.

IL-2, IFN- $\alpha$ and IFN- $\gamma$ may upregulate B7-H4 expression in 786-0 cells. The CCK- 8 assay, a proliferation assay that is directly proportional to the number of live cells in culture, was used as an independent measure of the proliferation in the IL-2-, IFN- $\alpha$ - and IFN- $\gamma$-treated 786- 0 cells. These results supported the fact that IL-2, IFN- $\alpha$ and IFN- $\gamma$ may inhibit the proliferative activity of 786-0 cells and exhibit a significant dose-effect correlation. The maximum drug concentration of a $1 \%$ cellular proliferation inhibition rate was $1,000 \mathrm{U} / \mathrm{ml}$. IL-2, IFN- $\alpha$ and IFN- $\gamma$ were applied at this concentration to stimulate the 786-0 cells in order to study the effect of IL-2, IFN- $\alpha$ and IFN- $\gamma$ on B7-H4 expression in ccRCC cells. The RT-PCR and IHC results showed that the protein (Fig. 2)and mRNA (Fig. 3) expression of B7-H4 may be upregulated by IL- 2 , IFN- $\alpha$ and IFN- $\gamma$, of which, IFN- $\gamma$ was the most capable. 
Table I. Clinical features of tumor B7-H4 expression.

\begin{tabular}{|c|c|c|c|c|}
\hline Feature & B7-H4 expression $(n=63)$ & B7-H4+ expression $(\mathrm{n}=91)$ & $\chi^{2}$ (Fisher) & P-value \\
\hline \multicolumn{5}{|l|}{ Gender } \\
\hline Male & 18 & 27 & \multirow[t]{2}{*}{0.022} & \multirow[t]{2}{*}{0.883} \\
\hline Female & 45 & 64 & & \\
\hline \multicolumn{5}{|c|}{ Age at surgery, years } \\
\hline$\geq 65$ & 20 & 28 & \multirow[t]{2}{*}{0.017} & \multirow[t]{2}{*}{0.898} \\
\hline$<65$ & 43 & 63 & & \\
\hline \multicolumn{5}{|c|}{2009 primary tumor classification } \\
\hline $\mathrm{T}_{1}$ & 52 & 52 & \multirow[t]{4}{*}{13.291} & \multirow[t]{4}{*}{0.004} \\
\hline $\mathrm{T}_{2}$ & 10 & 29 & & \\
\hline $\mathrm{T}_{3}$ & 1 & 9 & & \\
\hline $\mathrm{T}_{4}$ & 0 & 1 & & \\
\hline \multicolumn{5}{|c|}{ Regional lymph node involvement } \\
\hline $\mathrm{N}_{\mathrm{x}} / \mathrm{N}_{0}$ & 63 & 87 & \multirow[t]{2}{*}{4.282} & \multirow[t]{2}{*}{0.039} \\
\hline $\mathrm{N}_{1} / \mathrm{N}_{2}$ & 0 & 4 & & \\
\hline \multicolumn{5}{|c|}{ Distant metastases at nephrectomy } \\
\hline $\mathrm{M}_{0}$ & 63 & 86 & \multirow[t]{2}{*}{5.377} & \multirow[t]{2}{*}{0.020} \\
\hline $\mathrm{M}_{1}$ & 0 & 5 & & \\
\hline \multicolumn{5}{|c|}{2009 TNM stage groupings } \\
\hline I & 50 & 53 & \multirow[t]{4}{*}{9.583} & \multirow[t]{4}{*}{0.022} \\
\hline II & 11 & 25 & & \\
\hline III & 1 & 6 & & \\
\hline IV & 1 & 7 & & \\
\hline
\end{tabular}

TNM, tumor-node-metastasis.
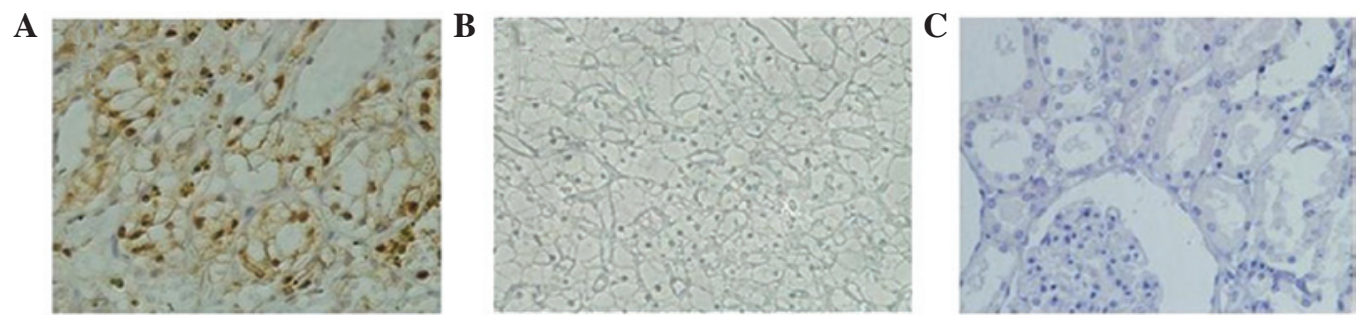

Figure 1. B7-H4 expression in normal kidney and RCC tissues. (A) Representative RCC tumor specimen with marked membranous tumor cell B7-H4 immunohistochemical staining. (B) RCC tumor specimen with negative tumor cell B7-H4 endothelial staining. (C) Normal tumor-adjacent kidney specimen without B7-H4 staining (magnification, x200). RCC, renal cell carcinoma.
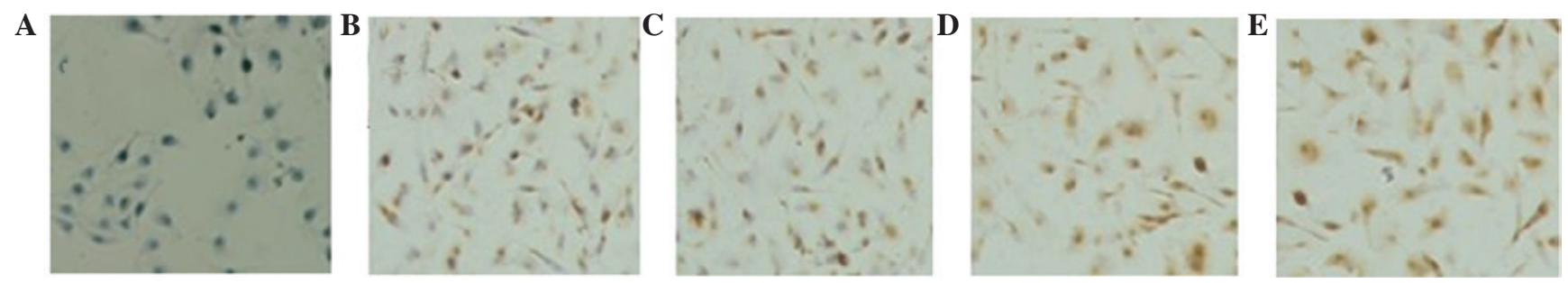

Figure 2. B7-H4 protein expression in 786-0 cells. (A) Negative control; (B) unstimulated; (C) stimulated by interleukin-2; (D) stimulated by interferon (IFN)- $\alpha$; and (E) stimulated by IFN- $\gamma$ (magnification, $\mathrm{x} 200)$.

The ELISA assay was used to detect the quantitative expression of soluble B7-H4 (sB7-H4) in the IL-2-, IFN- $\alpha-$ and IFN- $\gamma$-treated 786-0 cells. The sB7-H4 expression was detected in the unstimulated $786-0$ cells at a concentration of $34.42 \pm 1.69 \mathrm{ng} / \mathrm{ml}$. Following stimulation with IL-2, IFN- $\alpha$ and IFN- $\gamma$ for $24 \mathrm{~h}$, the concentrations increased to 


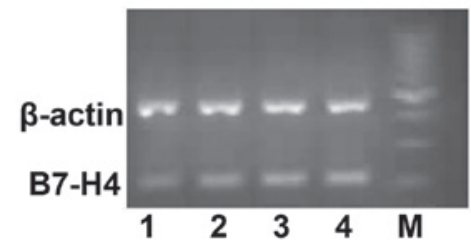

Figure 3. B7-H4 mRNA expression in 786-0 cells: 1 , unstimulated; 2 , stimulated by interleukin-2; 3 , stimulated by interferon (IFN)- $\alpha$; 4 , stimulated by IFN- $\gamma$; and M, DNA marker.
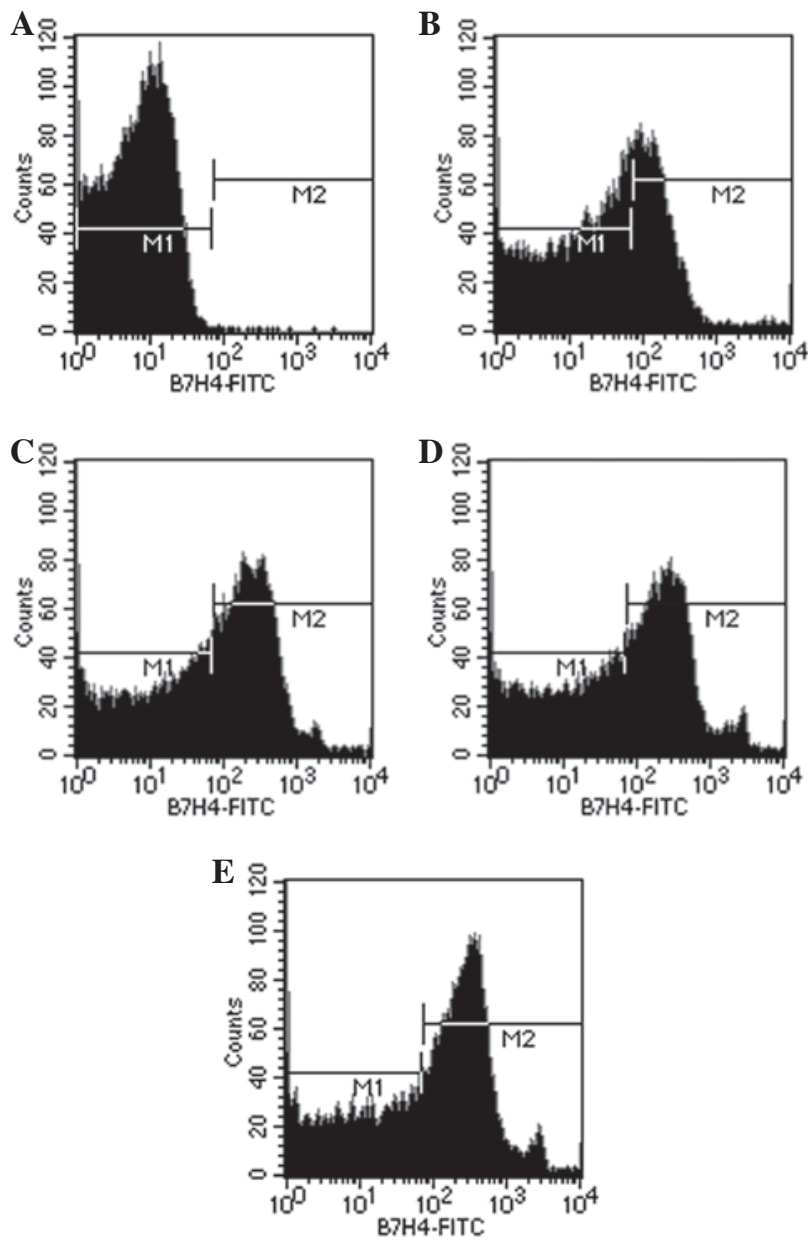

Figure 4. B7-H4 positive expression in 786-0 cells. (A) Control. (B) Unstimulated. (C) Stimulated with IL-2. (D) Stimulated with IFN- $\alpha$. (E) Stimulated with IFN- $\gamma$.

$44.89 \pm 0.97 \mathrm{ng} / \mathrm{ml}, 46.74 \pm 2.25 \mathrm{ng} / \mathrm{ml}$ and $47.31 \pm 1.12 \mathrm{ng} / \mathrm{ml}$, respectively, in which the differences were statistically significant $(\mathrm{P}<0.05)$. Flow cytometry (Fig. 4), which supplied quantified results of the positive expression of $\mathrm{B} 7-\mathrm{H} 4$ in the 786- 0 cells, revealed similar results. The positive expression rate of B7-H4 in the unstimulated 786- 0 cells was $30.45 \pm 0.96 \%$. Following stimulation with IL-2, IFN- $\alpha$ and IFN- $\gamma$ for $24 \mathrm{~h}$, the positive expression rates became $44.89 \pm 0.94,46.41 \pm 0.55$ and $54.18 \pm 1.42 \%$, respectively, which were significantly different compared with the unstimulated cells $(\mathrm{P}<0.05)$. The $786-0$ cells stimulated by IFN- $\gamma$ were the most capable, and the positive expression rate was significantly different compared with the other three groups $(\mathrm{P}<0.05)$. However, no significant difference was identified between the cells stimulated by IL-2 and IFN- $\alpha(\mathrm{P}=0.235)$.

B7-H4 is a negative regulator of T-cell cytotoxicity. To determine the role of $\mathrm{B} 7-\mathrm{H} 4$ in $\mathrm{T}$-cell responses, different ratios of effector to target cells (30:1, 20:1 and 10:1) were applied. CCK- 8 was used to detect the cytotoxicity of the T cells. The results showed that masking $\mathrm{B} 7-\mathrm{H} 4$ with a specific blocking $\mathrm{Ab}$ increased the T-cell killing of the 786-0 cells $(\mathrm{P}<0.05)$. With the increase of the concentration of effector cells, the cytotoxicity also increased significantly $(\mathrm{P}<0.05)$. This identified the inhibitory role of B7-H4 in T cell-dependent cytotoxicity, as in other tumor cell models (3).

\section{Discussion}

RCC is a typical immunogenic tumor frequently harboring high levels of tumor-infiltrating $\mathrm{T}$ lymphocytes and occasionally exhibiting spontaneous regression of metastases following primary tumor removal (10-12). As it is refractory to radiation and chemotherapy, immunotherapy, including the use of IFN- $\alpha$ and IL-2, is the main treatment choice for mRCC without surgery. However, in previous studies, the efficacy of IL-2 and IFN- $\alpha$ has been extremely low in mRCC and it has not been possible to observe the efficacy of $\operatorname{IFN}-\gamma(1,2)$.

The costimulatory B7 family members not only provide positive signals to stimulate T-cell activation, but also deliver negative signals to inhibit T-cell responses. Identified in 2003, B7-H4 represents the newest member of the B7 family of costimulatory ligands (13-15). Despite widespread B7-H4 mRNA expression in various human tissues, the lack of immunohistochemical staining of B7-H4 in the majority of normal human tissues indicates that the expression of $\mathrm{B} 7-\mathrm{H} 4$ is relatively restricted (6). B7-H4 is a type I transmembrane protein, and expression may be detected in various types of human cancer tissues, including breast (4), ovarian (5), pancreatic (6) and lung (7) cancer, melanoma (8) and RCC (9). The expression of B7-H4 has been found to correlate with advanced stages, poor patient survival and tumor infiltration by $\mathrm{T}$ regulatory cells (16), which made it a candidate of choice for targeted therapy. Notably, in the present study, positive B7-H4 expression was associated with adverse clinical features in ccRCC, which indicated that B7-H4 may be a feasible candidate of choice for RCC-targeted therapy.

Tumor infiltrating lymphocytes may be a manifestation of antitumor immunity, but a more abundant infiltration of tumor tissue $\mathrm{T}$ cells has been associated with a shorter survival of the RCC patients (11), which indicated that there is a potential failure mechanism of T-cell immunity in RCC tissues. The immunological mechanism mediated by $\mathrm{T}$ cells is also the main therapeutic target in the IL- 2 and IFN- $\alpha$ treatment of mRCC patients. The results of the present study demonstrated that IL-2, IFN- $\alpha$ and IFN- $\gamma$ may upregulate the expression of B7-H4, which may inhibit the proliferation and cytokine production of $\mathrm{CD}^{+}$and $\mathrm{CD}^{+} \mathrm{T}$ cells. Additionally, IFN- $\gamma$ was found to be the most capable for this, which indicated that the immune escape pathway induced by B7-H4 may be one of the most important reasons for the low efficacy of IL-2 and IFN- $\alpha$ and the inability to observe the efficacy of IFN- $\gamma$ in mRCC treatment. 
The current study further evaluated the functional ability to reverse T-cell inhibition mediated by the $\mathrm{B} 7-\mathrm{H} 4$ protein, which indicated that masking B7-H4 with a specific blocking Ab may increase the cytotoxicity of $\mathrm{T}$ cells in ccRCC. These results confirmed that B7-H4 is a regulatory molecule engaged in negative signaling that impacts anti-responses mediated by $\mathrm{T}$ cells in ccRCC, and also establishes a new paradigm for ccRCC cell eradication using B7-H4-based targeting. The study indicates that the blocking of B7-H4/B7-H4 ligand interactions may represent a feasible therapeutic strategy for ccRCC.

Targeting immune checkpoint molecules, such as CTLA4 and $\mathrm{B} 7-\mathrm{H} 1$, has elicited marked clinical responses, particularly in patients with pre-existing immune responses (17-19). Based on our studies, we propose that the blocking of B7-H4/B7-H4 ligand interactions may be used as a potential treatment for RCC patients. In addition, B7-H4 detection may be used to select the appropriate treatment for RCC patients. RCC patients whose TMA shows positive expression of B7-H4 must not select IFN- $\alpha /$ IL-2 treatment alone, since the T-cell-mediated antitumor responses must have been repressed by the B7-H4 mediated immune escape pathway. B7-H4 blocking treatment alone or combined with IFN- $\alpha /$ IL-2 may be more suitable for $\mathrm{B} 7-\mathrm{H} 4^{+}$patients.

\section{Acknowledgements}

The authors would like to thank Shiyong Huang, Jianhui Chen, Desheng Zhu, Yiming Su, Rongjin Fang, Cheng Zhao, Zhao $\mathrm{Hu}$, Youbiao Wang and Xiyuan Mu for participating in useful discussions. The current study was funded by grants from project support from the Appropriate Technical Transformation of Zhejiang (no. 2013ZHB001) and the Outstanding Scientific Research and Talent Cultivation of Zhejiang Cancer Hospital (no. 2012YC004).

\section{References}

1. Yang JC, Sherry RM, Steinberg SM, et al: Randomized study of high-dose and low-dose interleukin-2 in patients with metastatic renal cancer. J Clin Oncol 21: 3127-3132, 2003.

2. Fyfe G, Fisher RI, Rosenberg SA, et al: Results of treatment of 255 patients with metastatic renal cell carcinoma who received high-dose recombinant interleukin-2 therapy. J Clin Oncol 13: 688-696, 1995.
3. Dangaj D, Lanitis E, Zhao A, et al: Novel recombinant human b7-h4 antibodies overcome tumoral immune escape to potentiate T cell antitumor responses. Cancer Res 73: 4820-4829, 2013.

4. Tringler B, Zhuo S, Pilkington G, et al: B7-h4 is highly expressed in ductal and lobular breast cancer. Clin Cancer Res 11: 1842-1848, 2005

5. Kryczek I, Zou L, Rodriguez P, et al: B7-H4 expression identifies a novel suppressive macrophage population in human ovarian carcinoma. J Exp Med 203: 871-881, 2006.

6. Choi IH, Zhu G, Sica GL, et al: Genomic organization and expression analysis of $\mathrm{B} 7-\mathrm{H} 4$, an immune inhibitory molecule of the B7 family. J Immunol 171: 4650-4654, 2003.

7. Sun Y, Wang Y, Zhao J, et al: B7-H3 and B7-H4 expression in non-small-cell lung cancer. Lung cancer 53: 143-151, 2006.

8. Quandt D, Fiedler E, Boettcher D, et al: B7-h4 expression in human melanoma: its association with patients' survival and antitumor immune response. Clin Cancer Res 17: 3100-3111, 2011.

9. Krambeck AE, Thompson RH, Dong H, et al: B7-H4 expression in renal cell carcinoma and tumor vasculature: associations with cancer progression and survival. Proc Natl Acad Sci USA 103: 10391-10396, 2006.

10. Bromwich EJ, McArdle PA, Canna K, et al: The relationship between T-lymphocyte infiltration, stage, tumour grade and survival in patients undergoing curative surgery for renal cell cancer. Br J Cancer 89: 1906-1908, 2003.

11. Nakano O, Sato M, Naito Y, et al: Proliferative activity of intratumoral CD8(+) T-lymphocytes as a prognostic factor in human renal cell carcinoma: clinicopathologic demonstration of antitumor immunity. Cancer Res 61: 5132-5136, 2001.

12. Couillard DR and DeVere-White RW: Surgery of renal cell carcinoma. Urol Clin North Am 20: 263-275, 1993.

13. Zang X, Loke P, Kim J, et al: B7x: a widely expressed B7 family member that inhibits $\mathrm{T}$ cell activation. Proc Natl Acad Sci USA 100: 10388-10392, 2003.

14. Prasad DV, Richards S, Mai XM and Dong C: B7S1, a novel $\mathrm{B} 7$ family member that negatively regulates $\mathrm{T}$ cell activation. Immunity 18: 863-873, 2003 .

15. Sica GL, Choi IH, Zhu G, et al: B7-H4, a molecule of the B7 family member, negatively regulates $\mathrm{T}$ cell immunity. Immunity 18 : 849-861, 2003.

16. Kryczek I, Wei S, Zhu G, et al: Relationship between B7-H4, regulatory $\mathrm{T}$ cells, and patient outcome in human ovarian carcinoma. Cancer Res 67: 8900-8905, 2007.

17. Brahmer JR, Tykodi SS, Chow LQ, et al: Safety and activity of anti-PD-L1 antibody in patients with advanced cancer. N Engl J Med 366: 2455-2465, 2012.

18. Topalian SL, Hodi FS, Brahmer JR, et al: Safety, activity, and immune correlates of anti-PD-1 antibody in cancer. N Engl J Med 366: 2443-2454, 2012.

19. Ribas A: Tumor immunotherapy directed at PD-1. N Eng J Med 366: 2517-2519, 2012. 